\title{
Agroforestry systems, legislation and sustainability of small farms in Rio Grande do Sul, Brazil
}

\author{
Míriam Helena Kronhardt ${ }^{1,2}$, Julia Gastmann ${ }^{3}$ (D), Claudimar Sidnei Fior ${ }^{4}$, Elisete Maria de Freitas ${ }^{3}$
}

\author{
10.1590/0034-737X202168060001
}

\begin{abstract}
Agroforestry systems (AFS) represent an alternative to the current agricultural model, based on monoculture, mechanization, and intensive use of agrochemicals. The aim of this study was to characterize existing AFS in the Southern region of Brazil and understand how their forestry certification process is conducted by the official governmental body (SEMA-RS). Interviews were carried out with the owners of five AFS and one technical visit was made to SEMARS. Changes in production model resulted from a process of raising farmers awareness, which was observed when the main reason mentioned by farmers for implementing AFS is to ensure a healthier life quality. Another reason mentioned is that this system is economically and environmentally feasible and complies with current legislation. On the other hand, SEMA-RS facilitated the certification process by developing a simplified and quicker modality for AFS. The support of technicians and associations helps by providing access to information and to a successful production. This study confirms the effectiveness of AFS and the need to further their visibility so that they are implemented in other locations, especially in degraded areas, thus contributing with environmental preservation and with improving the health of the population, from farmers to consumers.
\end{abstract}

Keywords: agricultural model; degraded area recovery; family farming; forestry certification; natural ecosystems.

\section{INTRODUCTION}

Although agricultural production is based on family farming, it follows the conventional system, which is predominant throughout the country and the world (IBGE, 2010). Additionally, it has caused damages to both ecosystems and society, which suffers from food insecurity and health-related problems. It has also led to the loss of large areas with natural vegetation cover and has compromised Brazilian biomes (Ramos et al., 2009), compelling small-scaled landowners to abandon the activity and move to urban centers (Dal Soglio, 2016).

In face of this scenario, it is of the essence to search for more sustainable alternatives using natural resources (Wedig, 2009), such as agroforestry systems (AFS), which associate food production with the preservation of natural resources. They comprise agricultural production systems that consider independent ecological processes for a sustainable production, as they ensure optimal soil conditions (Gliessman, 2000), and help to restore the native forest patrimony and to recover degraded areas (May \& Trovatto, 2008). They also comply with environmental legislation concerning the recovery of permanent protection areas (APP) or legal reserves (RL) (Quoos, 2009).

In the specific context of the southernmost region of Brazil, according to records of the governmental body that handles environmental and sustainable development issues (SEMA-RS), 65 farms were granted Agroforestry Certification by the end of 2018. Despite this number, the information about implementation, operation and financial viability of this agricultural production system is still scarce. The spread of information about it can encourage the implementation of similar systems, because we hypothesize that AFS constitute an economic and

\footnotetext{
Submitted on July 29th, 2020 and accepted on March $21^{\text {th }}, 2021$.

${ }^{1}$ This work is part of the Master's Dissertation of the "Programa de Pós-Graduação em Sistemas Ambientais Sustentáveis" by the first author. The work had no funding source.

2 Universidade do Vale do Taquari - Univates, Museu de Ciências Univates, Lajeado, Rio Grande do Sul, Brazil. miriamhk@univates.br

${ }^{3}$ Universidade do Vale do Taquari - Univates, Laboratório de Botânica, Lajeado, Rio Grande do Sul, Brazil. julia.gastmann@universo.univates.br; elicauf@univates.br

${ }^{4}$ Universidade Federal do Rio Grande do Sul, Faculdade de Agronomia, Departamento de Horticultura e Silvicultura, Porto Alegre, Rio Grande do Sul, Brazil. csfior@ufrgs.br

*Corresponding author: julia.gastmann@universo.univates.br
} 
environmental viable alternative. Also, the agroforests must be structured starting from a selection of species that meet the interests of the rural producer and that are adjusted to the local environmental characteristics, aiming ecological balance. Therefore, the aims of this study were to become familiar with and characterize agroforestry systems that either have been exploited or aim to be commercially exploited, and observe how SEMA-RS is handling the certification of agroforestry systems in the State.

\section{MATERIAL AND METHODS}

Five rural properties with agroforests in their territories were visited in the south of Brazil and designated as AFS-A, AFS-B, AFS-C, AFS-D, and AFSE. Four of these farms are being economically exploited and one (AFS-B) is under implementation. With $12.3 \mathrm{hec}$ tares, of which 11 are intended for agroforestry, AFS-A is a farm located in the region of the Upper Hillside of Northeastern Rio Grande do Sul (RS), in a Deciduous Seasonal Forest. AFS-B, a property with 3.5 hectares, from which 2.5 hectares are agroforestry without economic exploration, is located in the region of Campos de Cima da Serra (RS) in a Mixed Ombrophilous Forest. AFS-C and AFS-E, with 17 and 20 hectares, respectively, are situated in the hillside of Serra Geral, in the northeastern region of the coastline of RS, with vegetation classified as Dense Ombrophilous Forest. The owner of AFS-C didn't know the total area allocated to the agroforestry in their property, while AFS-E had three hectares. AFS-D, with a total area of 9.8 hectares and 0.5 hectares of agroforestry, is located in the Pampa biome (RS), in the vicinity of the Southeastern Range.

Data sampling was qualitative through in loco observation and approach through interviews with the owners of the five AFS and on-site visits to the agroforests in each property. The interviews, conducted through informal conversation with each landowner, were based on an adapted script by Ferreira (2014). The covered topics were as follows: (1) conditions of the agroforestry area before its implementation; (2) planning followed for the AFS implementation; (3) species used in the AFS and their functions in the system implementation (fertilizer spreaders, pioneers and secondary species) and forms of economic exploration; (4) management practices adopted in the AFS and if they follow agroecology principles; (5) association of the farmers to networks or cooperatives; (6) knowledge about the certification that allow products' commercialization; and (7) economic viability of the property. Additionally, one of the technicians responsible for the licensing of forestry products was interviewed in order to know the procedures required by SEMA-RS to obtain the Forestry Certification.

\section{RESULTS}

\section{Brief history and causes for the implementation of agroforests}

Since the mid-1980s, the owner of AFS-A has invested in non-conventional citrus. Eighteen years later, he noticed that plants cultivated near forests had more vigorous leaves and lower disease incidence. Therefore, he started to allow certain native plants to grow, thus developing a more shaded environment. He had therefore started an agroforestry system. The property is currently a reference in agroforestry management in RS, and it has been part of the touring route in the region since 2007 .

Agroforest AFS-B is not economically exploited, yet, as it is under implementation. Before it was acquired six years ago, it was used for continuous cattle grazing. One of these grazing areas is currently in the early phase of natural regeneration. In another part, seedlings of native species and exotic species were inserted in order to start implementing the agroforest.

In AFS-C, one part of the agroforest results from the change in areas previously used for conventional agriculture, with occurrence of erosion due to land declivity. Another part of the agroforest results from the management of a native forest area. This production system was chosen after the landowner had health issues and needed to live a healthier lifestyle. Today, he believes that "We need to adapt to nature in order to live in harmony. When we use drugs on the plants, these drugs pass on to us".

With knowledge of agroecology and an entrepreneurial view, the owner of AFS-D started organic production after having intoxication by agrochemicals. Once he recovered, he started taking courses at the Center for Support to Small Farmers (Capa), planting short-cycle species in an ecological manner, and reforested part of his property. Currently, with the technical support provided by the team of the Brazilian Company of Agricultural ResearchEmbrapa Clima Temperado, he has started to implement four agroforests, alternating them with areas where organic food is produced in simplified systems (with few crops). He strived to change his cultivation method in the beginning, as it was necessary to recover the soil, which had been degraded by intensive use of agrochemicals and burns. Phytosanitary problems ended when soil conditions improved and, for the owner, "There is no such thing as pests in Nature; what there is, are hungry animals. If you give them food, your problems are solved."

The owner of AFS-E also used to carry out conventional production. Due to health problems, he started implementing an orchard, interspersing native fruit trees with exotic ones, and then, widening its cultivation area gradually. According to him, "Nature changes each day, 
and now I have good water and better health." In another area of his property, he removed part of the trees in the forest to increase incident light and to favour the production of marrows and yams.

This confirms what was stated by the other landowners to SEMA-RS technicians, that they chose to grow agroforests to have better life quality, cultivation with no agrochemicals, to supplement family income in a growing market niche (native plants and organic production), and for the personal satisfaction of working with native essences and on the land.

\section{Major species used and agroforestry management}

The choice of species is diverse and depends on the region and on farmers' interests, on environmental conditions, and on the potential for commercializing the produce. The most frequently used species are Musa spp. (banana), Euterpe edulis Mart. (jussara or heart of palm), Citrus spp. (citrus), Schinus terebinthifolius Raddi (aroeira-vermelha) and Eucalyptus spp. (Eucalyptus). Vegetables and different plants considered nonconventional edible foods (PANC), such as yams and potato yams, among others, are also cultivated. Agroforests in AFS-C, AFS-D, and AFS-E have higher biodiversity, with tree species, medicinal species, vegetables, and other annual crops (grains). In AFS-A, production is based on Citrus spp. (orange, lime, and tangerine) and banana trees, associated with native trees, but with no commercial exploitation.

As a member of the project "Cadeia solidária das frutas nativas do RS" (Solidary chain of native fruits from $\mathrm{RS}$ ), the production in AFS-B is based on native species, such as Araucaria angustifolia (Bertol.) Kuntze (pine tree), Psidium cattleianum Sabine (araçá), Ilex paraguariensis A.St.-Hil. (Yerba mate), Tropaeolum pentaphyllum Lam. (crem) and Rubus brasiliensis Mart. (amora-branca - white mulberry). According to the interviewee, "Many people are afraid of dealing with biodiversity, but this mindset needs to be reversed." Musa spp. (banana trees) and E. edulis (jussara or palm trees) are cultivated in large amounts in AFS-C, associated with native tree species. Another major focus in their production are non-conventional edible foods (PANC) (Xanthosoma riedelianum (Schott) Schott (taioba), Curcuma longa L. (saffron), Colocasia esculenta (L.) Schott (yam), Dioscorea bulbifera L. (cará-moela)) and spices and medicinal plants (Petroselinum crispum (Mill.) Fuss (parsley), and Melissa officinalis L. (lemon balm).

In AFS-D, banana seedlings comprise the agroforests in the property. In another agroforest, which is an experimental station of Embrapa Clima Temperado, a biodiverse agroforestry system was implemented with native species for different uses: Eugenia pyriformis Cambess. (uvaia tree), Acca sellowiana (O. Berg) Burret (goiabeira-serrana), Eugenia uniflora L. (pitangueira), S. terebinthifolius, I. paraguariensis and Ananas comosus L. Merril (pineapple). Additionally, they grow Citrus spp. and wild flowers of different species. For its establishment, two seedlings of fruit species were interspersed with one largesized native species, and seedlings of ornamental plants were sown among these species, thus ensuring a yearround production. Specimens of S. terebinthifolius are used as support for vineyard trellis systems, help to control erosion, produce good flowering for bees, their fruits are a source of food for the native fauna, and can be commercialized as pink pepper (pimenta-rosa). Therefore, the landowner emphasizes that everything in his property has its importance, both economic and environmental.

Crops in the agroforests of AFS-E are quite diversified, composed of fruit trees, vegetables, and grains, maintained randomly in the agroforest. Since its land is quite sloped, specimens of E. edulis (at different growth stages) and eucalyptus are kept on the upper part. At another point, there are fruit species such as Persea americana Mill. (avocado), Campomanesia xanthocarpa (Mart.) O. Berg (guabiroba), Annona sp. (araticum), E. uniflora, Plinia peruviana (Poir.) Govaerts (jaboticabeira - blackberry), Annona muricata L. (graviola), Dyospyros spp. (khaki), Citrus spp., Rubus spp. (amoreiras - mulberry), Ananas bracteatus (Lindl.) Schult. \& Schult. f. (pineapple), and Coffea sp. (coffee). Closer to the house, the landowner grows vegetables such as yam, garlic, onions, saffron, and cará (aerial yam). He uses organic matter derived from pruning and boiled manure for soil fertilization. The second agroforest in the property results from the extraction of native trees from the forest and introduction of timber species, E. edulis, and marrows. He maintains beehives in both agroforests for the production of honey and for stimulating crop pollination.

The management of all agroforests visited is similar, with selective mowing, maintenance of plants of interest, and pruning to control the amount of light according to the need of the plants grown. Another common practice is depositing materials derived from pruning inside the agroforest in order to develop organic matter and minerals from their decomposition for soil fertilization, which maintains a good nutrient level. Some procedures are specific to each property. As an example of interaction between species and biological control, sunflowers are cultivated in AFS-D to attract ladybugs, which are predators of aphids, thus keeping the balance between populations to prevent them from becoming pests. AFSA farmer follows some biodynamic principles, such as planting and pruning calendars, and horn manure in homeopathic dosages for soil fertilization. This same 
farmer has not used agrochemicals for 20 years and fertilizes plantlets using an organic compost obtained at an ecological farmers' cooperative. Stone meal and boiled manure were used at AFS-B to recover soil nutrients during the agroforest implementation, and plant-based preparations are used to fight pests at AFS-C.

Plant observation is a constant practice at AFS-D. Therefore, once the excessive growth of plants is observed, when there is emission of a large number of sprouts and leaves that might cause muffling and consequently favor fungus growth, they introduce grasses (oat, maize, and ryegrass), which absorb nitrogen. Thus, is re-establish soil balance, as excess nitrogen leads to excessive growth of plants. He also mentioned that the emergence of ferns indicates soil acidity, and lime must be used to increase $\mathrm{pH}$. He finished by saying, "Nature explains everything to us, it provides all the answers, it is wise, and we need to learn from it."

\section{Economic feasibility and farmers' support entities}

Of the five landowners interviewed, four live off their property and claim that it is economically feasible to commercialize agroforestry products, thus generating income to provide for the family livelihood. According to them, financial growth results from the fact that they do not have to buy supplies. The owner of AFS-B does not depend economically on his agroforest but says that its implementation is intended to provide for his family in the future.

According to the owner of AFS-A, who receives guidance from agronomists of a Cooperative and takes courses in the agroecology field, his agroforest has caused production to increase and has provided higher financial return; his income is already four times higher with the agroforestry system than if he planted soy, for example. The commercialization of products, especially NonConventional Edible Plants (PANC), in fairs of neighbouring cities is what provides support to AFS-C, and its income is higher due to direct sale to consumers and to the fact that its expenses are restricted to the transport of produce. Showing how pleased he is, and referring to PANC, he says: "What I sell is remedy".

Having entrepreneurial vision, the owner of AFS-D is always innovating and creating alternatives to make his property more productive and profitable. Unlike the other properties, he practices sustainable extraction of native ornamental plants. He sells most of his products in fairs of neighbouring cities and processes the remainder in a small agroindustry inside his property, producing juice, jam, and preserves. Due to diversification of crops, most of the products consumed by his family derive from the property land, and their expenses with subsistence is low.
This landowner is a member of the Regional Association of Agroecologist Producers of the Southern Region (ARPA-SUL) and of the Agroecology Network Ecovida and is always searching for further training courses, as well as exchanging experiences with other farmers and technicians, mostly from Embrapa Clima Temperado.

The independence of commercializing his own products, reached by the owner of AFS-E, who is a partner at the Mixed Cooperative of Family Farmers of his municipality, is targeted at cutting off intermediaries, increasing sales, and consequently, increasing his family income since direct sales are more profitable. He initially sold his products to supply centers in RS. Then, he started selling at the fair of a neighbouring town and products intended for school meals to the city hall of the municipality where he lives.

\section{Legislation, certification, and support of AFS in RS}

Aware of the need for normalizing areas occupied by agroforests in RS and for simplifying forestry certification based on current laws, which require thirteen forestry licenses for native vegetation management, SEMA-RS technicians have developed a single licensing and certification document for agroforests, with annual renewal upon the submission of a report. For that purpose, technicians visit the property and help landowners to fill in the registrations, and then, they provide the document with all permits and restrictions, according to the characteristics of the property, thus ensuring exploitation and sustainable use of the forest. Prior to this new form of regulation, landowners had to request licenses for each situation, and some of them had to submit specific projects elaborated by technicians, which rendered legalization and management of native plant species a lengthy and economically unfeasible process for small rural properties. Unlike other licensing processes, the Agroforestry Certification does not require payment of fees once the property falls within up to four fiscal modules.

The creation of a new licensing/certification modality was based on legal devices that define family farmers, traditional communities, and small-sized rural properties for which procedures become differentiated and more flexible. However, the process of obtaining the license depends on the assessment of local environmental characteristics by technicians, and there is no single rule to be followed, except for the obligation not to mischaracterize the implementation area.

All properties visited in this study were granted Agroforestry Certifications by SEMA-RS for their implementation and management. In addition, AFS-A and AFS-D have their products certified as organic. AFS-C, on the other hand, has a certification of organic producer 
provided by the Participative Conformity Assessment Body (OPAC), of which the owner is a member. One example of permits or restrictions found in the certificates is that the management of native vegetation for the opening of trails, understory management for entrance of light, and even the pruning of threatened species such as Araucaria angustifolia is allowed in AFS-B as this property has no vegetation in advanced stage of regeneration. On the other hand, in APP areas, only sustainable management is permitted through the collection of fruits and seeds, as long as there is no mischaracterization of the area. In AFS-C, planting and management of native plants are allowed, including species found in the threatened species list, such as E. edulis.

\section{DISCUSSION}

Roiz-Díaz et al. (2018) analysed interviews conducted with 183 farmers from eight European countries in 14 different productive systems in order to identify benefits and costs of agroforestry practices. Of the total interviewees, 98 had some type of agroforestry system and others, although they had chosen more sustainable agricultural practices, such as organic agriculture, were not even aware of the concept of agroforestry. In spite of that, family tradition was considered the major reason for living off the conventional system as well as the fact that it is easier to manage. They also admitted to not being knowledgeable of agroforestry systems and that they did not consider agroforests as an economically feasible option as it requires more investment for its establishment and maintenance, since agroforestry producers have neither added value nor market demand. The same farmers said that agricultural production is lower when associated with trees, as opposed to what agroforestry farmers advocate. Additionally, the same authors observed that younger farmers were the most interested in introducing innovative practices in agriculture.

Studying farmers who have agroforests, Roiz-Díaz et al. (2018) pointed out that the major reason for choosing this system derives from family or regional traditions, followed by diversification of products and learning from others, therefore showing similarities between agroforestry farmers and conventional system farmers. This does not seem to be the case of the farmers interviewed in the present study, who pointed out the search for a healthier life, lower impact on the environment, and reduction of costs by using resources derived from the property as the major reasons for choosing agroforests.

Similar to the farmers in the present study, those interviewed by Roiz-Díaz et al. (2018) claimed that agroforestry systems provide the diversification of products (timber, fodder, meat, milk, crops) which in turn have higher quality, and thus contribute to increase yield and property profitability, maximizing income and reducing some costs. They also mention that agroforests provide pasture and fodder for animals, especially in the winter, and contribute with increased pollination, which was corroborated by the findings of Hass et al. (2018), who studied the visitation of bees in isolated rice crops and in agroforests. The authors observed that agroforests provide food and resources for the nesting of bees and, in exchange, they get pollination and biodiversity services for their production systems. In the conventional system, with isolated rice crops, bee visitation was lower, probably due to interrupted connectivity between bee habitats. Aside from stimulating pollination, one of the most important agroforestry services is certainly the fact that agroforests ensure synergies between their components, decreasing risks in production due to climatic events or market changes (Roiz-Díaz et al., 2018).

Vieira et al. (2007) found similar results as those of the present study when working with family farmers in Pará, Brazil. In the referred study, the choice of agroforestry practices was based on farmers' personal and cultural characteristics, and they mentioned protecting the environment and family income as reasons for their choice. Production diversification, higher financial independence, and increased balance in the systems were also indicated by May \& Trovatto (2008) based on the report of experiences provided by landowners who changed conventionally-cultivated areas, exposed to chemical fertilizers and agrochemicals, into AFS. This shows that they realized how much production mode affects the balance in the location where they live, and that these choices are related with quality of life of people who produce and consume these foods.

The production mode adopted by the agroforestry farmers interviewed is frequently based on past experiences, but always with an eye to the future of the family, which also corroborates the study by Roiz-Díaz et al. (2018), as their agroforestry farmers said this is a cultural heritage passed down from their parents. However, in the present study, the importance of technical counselling and the association with cooperatives to improve yield and economic efficiency in the properties was highlighted. Wives \& Machado (2014) claimed that technical counselling ensured the provision of information for organizing banana cultivation in the Northern coast of RS in order to make the best from the potentialities of the environment. According to the authors, economical gains in ecologically based production systems are related to the sale of products in differentiated markets, to the amounts produced, and to lower expenses, compared to areas that follow the conventional system. This is comparable to the properties in the present study. The commercialization of AFS-A products, with income based 
primarily on citrus production, is guaranteed by the Cooperative, thus ensuring financial safety. On the other hand, the owners of AFS-C, AFS-D, and AFS-E chose to sell their products directly to customers in agroecological fairs, ensuring higher financial return due to the elimination of intermediaries.

Being members of associations or cooperatives enables landowners to grow, both technically and culturally, as several aspects of production are discussed as well as the needs of members who also take part in the decision-making process (Lopes \& Almeida, 2003). What was observed in the present study is that the support provided by associative or cooperative networks is essential for implementing improvements in the management of the areas, for complying with legislation, and for commercializing products, thus ensuring a safer management and compliance with current legislation. According to Teixeira \& Pires (2017), technical counselling on ecological production and exchange of experiences between landowners provided by NGO's is also helpful and essential for their social condition and in securing their autonomy.

The potentialities of the environment, according to Wives \& Machado (2014), involve environmental conditions and biodiversity, since the economic feasibility of AFS depends on the species found in each one, and the higher the diversity, the higher the possibility of commercializing different products. This is what occurs at AFS-D, which commercializes products and ensures year-round income generation, thus providing for the families. Freitas et al. (2015) studying an AFS in Mato Grosso, showed the financial feasibility of AFS, since they reported that production costs are reduced, as farmers do not depend on external supplies. The commercialization of bananas produced in the property also generates a good income and the profit obtained with the commercialization of vegetables covered expenses with irrigation already in the first months of exploitation. In this regard, the owners of AFS$\mathrm{C}$ and AFS-D said they intend to make their properties increasingly productive for their children, in an attempt to ensure the permanence of young people in the rural area. According to Braga \& Silva (2013), this is attainable as increased family cohesion becomes evident once family members start to take most of their income from the property, whereas they are also involved in a collective project. Thus, they contemplate the need for higher income and better sociability conditions, which are currently the major causes for abandoning rural areas.

Reinforcing what has been mentioned regarding the potentialities of the surrounding area, species diversity contributes with pest control, as it provides shelter, food, and conditions for the survivorship of a high diversity of animals, fungi, and microorganisms that control pests, maintaining a balanced cultivation environment. This is confirmed by Farrelly (2016), according to whom agroecological systems promote increased complexity in live systems and ensure the conservation of local biodiversity, as opposed to conventional agriculture. However, this only happens when the landowner prioritizes local species, taking advantage of existing resources in the property, and builds systems adapted to local conditions, thus allowing for nutrient cycling. Therefore, no external resources are introduced in the property, making it more independent and profitable, which was mentioned by the interviewees in the present study.

Aside from being aware of the importance of preserving local biodiversity, landowners need to respect the principles of agroecology (Altiere, 2012), making sure that agroforestry functions are fulfilled. The removal of forest species, which occurred in one of the properties visited in the present study, is not recommended. However, as these are only small-sized farms, and local vegetation of this cohort is classified as secondary in a medium regeneration stage, Law $n^{\circ} 12.651$ (Brasil, 2012) allows for the removal of up to fifty percent of trees as a means to ensure the family's subsistence. This permission might be granted in special cases where the landowner has no area to increase production and this activity is essential for providing for the family. Unlike what has been mentioned, the agroforest at AFS-D is being installed in a degraded area with the purpose of re-establishing environmental balance, which is essential for the property's sustainability, since production systems ensure the recovery of degraded soils and diversified food production (Junqueira et al., 2013).

The species to be used in the AFS are chosen according to the role they play in the environment (fertilization and shading) or to the exploitation form (production of fruits and vegetables, timber, and annual crops) (Fernandes et $a l ., 2014)$. In the present study, it was evident that the choice of species was based on potential uses and according to the landowners' interests, as occurred also in the study by Fernandes et al. (2014) and Souza \& PiñaRodrigues (2013). Fernandes et al. (2014) showed the richness of Leguminosae used in 21 AFS implemented in forest fragments of the Atlantic Forest, in Minas Gerais, Brazil, classifying them according to use categories and importance (fertilization, human diet, soil cover, foraging, firewood, timber, medicinal, shading, construction, ecological and technological interaction). Of the total species exploited, 51 were native, which shows that the landowners interviewed had multiple uses for species of the Atlantic Forest biome. A higher interest in native species was also observed, which is not very common. 
Another differential in this study was the option for PANC, a new and growing market in Brazil.

Along with financial independence, agroforestry systems reconcile food production with environmental conservation. These environmental advantages have been demonstrated in studies such as by Fávero et al. (2008) who analysed four-year-old AFS implemented in Minas Gerais and observed higher availability of soil nutrients in a recovery area. Junqueira et al. (2013) observed soil decompaction, erosion control, increased soil moisture retention, increased plant indicators of good soil quality, and decreased incidence of pests and diseases in the settlement Sepé-Tiarajú, located in the sugarcane region of Ribeirão Preto.

Considering the current legislation, the interviews, the granting of certification for forest exploitation to all landowners of the present study, and the observations carried out in the AFS, it was evident that agroforestry landowners work in compliance with legislation and environmental preservation, which shows that the system implemented by SEMA-RS is fulfilling its mission. This corroborates the findings by Korting (2015) who claim that it is possible to legalize agroforests in accordance with legal provisions of the environmental legislation by granting certifications based on knowledge compiled by environmental technicians who seek to respect minimal attributes of environmental preservation and healthy food production. Moreover, as observed in the present study, this fosters a closer relationship between environmental bodies and farmers. There is a change in the perception the latter have of technicians, from supervisors who are there to punish to collaborators who can provide help for landowners to comply with legislation. Besides that, the simplification of certification procedures implemented by SEMA-RS technicians is an encouragement for those landowners who intend to comply with current laws. Also, the creation of public policies that stimulate the implementation of agroforestry systems is fundamental so more farmers can adhere to this productive model and promote an improvement of the community's quality of life.

\section{CONCLUSION}

The choice for implementing AFS is the result of a change in awareness caused by the difficulty to compete in the market and by the choice of a healthier lifestyle, in compliance with environmental legislation. Incentives and lessons learned from technicians and associations are essential for successful agroforests. It was evident that local conditions, market opportunities, and the need for maintaining a diverse system so that it self-regulates are determining factors in the choice of species. However, it is worth emphasizing the interest in native species and PANC, as the market for both of them has been growing.
It is important to show successful examples of agroforestry systems and their benefits in order to reach out to other landowners and consumers, especially regarding the quality of agroforestry products and agroecosystem services provided by agroforests.

\section{ACKNOWLEDGEMENTS, FINANCIAL SUPPORT AND FULL DISCLOSURE}

We are grateful to the landowners and their families, who welcomed the team of this research project, reported their stories and experiences, thus contributing to broadening our knowledge on this topic.

We also declare that there are no conflicts of interest.

\section{REFERENCES}

Altiere M (2012) Agroecologia: Bases científicas para uma agricultura sustentável. $3^{\text {rd }}$ ed. São Paulo, Expressão Popular/ASPTA. 400 p.

Braga PC \& Silva RM (2013) A construção do sujeito agroflorestal por meio da ética do habitar: Resistência e autonomia na visão de mundo agrofloresteira. In: Steenbock W, Silva LC, Silva RO, Rodrigues AS, Perez-Cassarino J \& Fonini R (Ed.) Agrofloresta, economia e sociedade. Curitiba, Kairós. p.155-196.

Brasil (2012) Lei $N^{\circ} 12.651$, de 25 de Maio de 2012. Dispõe sobre a proteção da vegetação nativa. Available at: http:// www.planalto.gov.br/ccivil_03/_ato2011-2014/2012/lei/ 112651.htm. Accessed on: January 20 2019.

Dal Soglio FK (2016) A agricultura moderna e o mito da produtividade. In: Dal Soglio F \& Kubo RR (Ed.) Desenvolvimento, agricultura e sustentabilidade. Porto Alegre, UFRGS Editora. p.11-38.

Farrelly M (2016) Contribuições da agroecologia para os objetivos de desenvolvimento sustentável. Agriculturas, 13:78-83.

Fávero C, Lovo IC \& Mendonça ES (2008) Recovery of degraded areas using agroforestry systems in Vale do Rio Doce, Minas Gerais. Revista Árvore, 32:861-868.

Fernandes JM, Garcia FCP, Amorozo MCM, Siqueira LC, Marotta CPB \& Cardoso IM (2014) Ethnobotany of Leguminosae among agroecological farmers in the Atlantic Forest, Araponga, Minas Gerais, Brazil. Rodriguésia, 65:539-554.

Freitas M, Thomas S, Pignati W \& Carmo B (2015) Sistemas Agroflorestais em Chapada dos Guimarães, Mato Grosso: Um Relato de Experiência do Grupo de Agroecologia da Universidade Federal de Mato Grosso. Cadernos de Agroecologia, 9:1-9.

Ferreira LR (2014) As Agroflorestas como expressões do desenvolvimento rural no Rio Grande do Sul: Uma análise a partir da produção de novidades. Master Dissertation. Universidade Federal do Rio Grande do Sul, Porto Alegre. 148p.

Gliessman SR (2000) Agroecologia: Processos Ecológicos em agricultura Sustentável. $1^{\text {st }}$ ed. Porto Alegre, UFRGS Editora. $656 \mathrm{p}$.

Hass AL, Liese B, Heong KL, Settele J, Tscharntke T \& Wesphal C (2018) Plant-pollinator interactions and bee functional diversity are driven by agroforests in rice-dominated landscapes. Agriculture Ecosystems \& Environment, 253:140-147.

Instituto Brasileiro de Geografia e Estatística - IBGE (2010) Censo demográfico. Available at: https://ww2.ibge.gov.br/home/ estatistica/populacao/ censo2010/. Accessed on: November $4^{\text {th }}$, 2018.

Rev. Ceres, Viçosa, v. 68, n.6, p. 503-510, nov/dec, 2021 
Junqueira AC, Schlindwein MN, Canuto JC, Nobre HGS \& Marques TJ (2013) Agroforestry and changes in soil quality in agrarian reform settlement. Revista Brasileira de Agroecologia, 8:102-115.

Korting MS (2015) Trama científica e jurídica na construção do certificado de agroflorestas. Norus, 3:118-137.

Lopes SB \& Almeida J (2003) Metodologia para análise comparativa de sustentabilidade em sistemas agroflorestais. Revista de Economia e Sociologia Rural, 41:79-110.

May PH \& Trovatto CMM (2008) Manual agroflorestal para a Mata Atlântica. $1^{\text {st }}$ ed. Brasília, Ministério do Desenvolvimento Agrário. 196p.

Quoos RD (2009) Sistemas Agroflorestais: Ferramentas da Biodiversidade para uma Agricultura Sustentável. In: Dal Soglio F \& Kubo RR (Ed.) Agricultura e sustentabilidade. Porto Alegre, UFRGS Editora. p.97-116.

Ramos SF, Chabaribery D, Monteiro AVVM \& Silva JS (2009) Sistemas agroflorestais: estratégia para a preservação ambiental e geração de renda aos agricultores familiares. Informações Econômicas, 39:37-48.

Roiz-Díaz M, Lovric N, Lovric M Ferreiro-Domínguez N, Mosquera-Losada MR, Herder M, Graves A, Palma JHN, Paulo JA, Pisanelli A, Smith J, Moreno G, García S, Varga A, Pantera A, Mirck J \& Burgess P (2018) Farmers' reasoning behind the uptake of agroforestry practices: evidence from multiple casestudies across Europe. Agroforestry Systems, 92:811-828.
Souza MCS \& Piña-Rodrigues FCM (2013) Evaluation of forest species in agroforestry systems applied to restoration of degraded areas at Ombrophilous Forest, Paraty, Brazil. Revista Árvore, 37:89-98.

Teixeira CTM \& Pires MLLS (2017) Análise da relação entre produção agroecológica, resiliência e reprodução social da agricultura familiar no Sertão do Araripe. Revista de Economia e Sociologia Rural, 55:47-64.

Vieira TA, Rosa LS, Vasconcelos PCS, Santos MM \& Modesto RS (2007) Agroforestry systems in areas of smallholder agriculture in Igarapé-Açu, Pará: floristic characterization, implantation and management. Acta Amazonica, 37:549-558.

Wedig JC (2009) Reflexões socioculturais acerca do mundo rural. In: Dal Soglio F \& Kubo RR (Ed.) Agricultura e sustentabilidade. Porto Alegre, UFRGS Editora. p.47-62.

Wives DG \& Machado JAD (2014) Influential factors and decision making in banana production systems in north coast of Rio Grande do Sul. Revista Brasileira de Gestão e Desenvolvimento Regional, 10:225-247. 